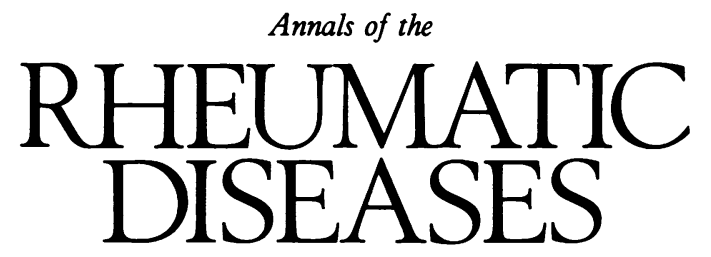

Leader

\title{
Diffuse pigmented villonodular synovitis: non-surgical management
}

Pigmented villonodular synovitis is a condition rarely seen by rheumatologists, and then almost always at the invitation of their surgical colleagues. At one time, referral was only after failure of one or more surgical synovectomies, but the increasing use of arthroscopy and early diagnosis by arthroscopic biopsy has resulted in referral of early cases. At this stage, older rheumatologists will remember the controversies surrounding protective early versus late synovectomy in rheumatoid arthritis. Similarly, in pigmented villonodular synovitis some of the cases now treated medically may include a proportion of the $54 \%$ whose synovitis did not recur after surgical synovectomy ${ }^{1}$ and even the occasional case whose synovitis remitted after open biopsy alone. A multicentre controlled trial would seem desirable, but there is insufficient information available on improvement rates with which to construct such a trial and as the condition is rare collecting sufficient cases might take years.

The classical point of view on the treatment of pigmented villonodular synovitis ${ }^{2}$ is that the degree of synovial thickening is usually too great for intra-articular treatment to be effective: a surgical synovectomy is necessary, followed by intra-articular radiotherapy using a larger dose (277 MBq of yttrium-90 rather than $185 \mathrm{MBq}$ for the knee) than for rheumatoid arthritis. Our experience with 13 patients treated at Northwick Park by this regimen is as follows ${ }^{3}$ : we found marked long term improvement in five out of six joints treated within five to six months of the first recurrence after initial or repeated synovectomy, but in six others treated at longer intervals after surgical synovectomy repeat injections were needed in five and two needed further surgery. Franssen et al clearly found a similar referral pattern as six of their patients had already undergone one or more surgical synovectomies, and were treated with one or two injections of $185 \mathrm{MBq}^{90} \mathrm{Y}$ on average 27 months after synovectomy. ${ }^{4}$ The improvement in one patient was excellent; two were moderately improved. In part, these results may reflect the chronicity and extent of the disease as well as irreversible articular cartilage damage: the ultimate determinant of success or failure.

Best results were obtained in two patients without previous surgical synovectomy, with shorter duration of disease (and shorter period of follow up), treated with one or two injections of $185 \mathrm{MBq}{ }^{90} \mathrm{Y}$. These results echo the experience of O'Sullivan et al, who obtained excellent results in three early cases ${ }^{5}$ : after one injection of $185 \mathrm{MBq}$ in one case and in two cases with two injections of ${ }^{90} \mathrm{Y}$ with a three to four year follow up period. A fourth patient was irradiated, years after the onset of the disease and initial synovectomy but was left with severe joint damage.

The variability in symptoms, signs, ultimate degree of damage, and response to treatment in pigmented villonodular synovitis is difficult to appreciate without extensive experience; the potential for damage can be seen in the nuclear magnetic resonance images of one patient in our original series (fig 1) and one tabulated here (fig 2). In our recent patients, who had minimal synovitis, we attempted to reproduce the good results obtained by O'Sullivan et al. Tables 1 and 2 show the results obtain : $d$ in these and other recently treated patients, which are as yet difficult to

Table 1 Patients with no previous surgery other than arthroscopic biopsy. The right knee affected in each case

\begin{tabular}{|c|c|c|c|c|c|c|c|}
\hline \multirow{2}{*}{$\begin{array}{l}\text { Case } \\
\text { No }\end{array}$} & \multirow[t]{2}{*}{ Sex } & \multirow{2}{*}{$\begin{array}{l}\text { Age } \\
\text { (years) }\end{array}$} & \multirow{2}{*}{$\begin{array}{l}\text { Date of } \\
\text { onset }\end{array}$} & \multirow{2}{*}{$\begin{array}{l}\text { Initial } \\
\text { condition }\end{array}$} & \multicolumn{3}{|l|}{ Stages of treatment and outcome } \\
\hline & & & & & $l$ & 2 & 3 \\
\hline 1 & $\mathbf{F}$ & 21 & Dec 1987 & Bulky synovial hyperplasia & $\begin{array}{l}\text { Surgical synovectomy } \\
\text { Jan } 1988\end{array}$ & $\begin{array}{l}\text { No recurrence Jan } 1990, \\
\text { but flexion only to } 60^{\circ}\end{array}$ & \\
\hline 2 & $\mathbf{M}$ & 62 & May 1988 & Minimal synovial thickening & $370 \mathrm{MBq}{ }^{\prime * /} \mathrm{Y}$ Nov 1988 & $\begin{array}{l}\text { Asymptomatic but small } \\
\text { effusion Mar } 1990\end{array}$ & \\
\hline 3 & $\mathbf{F}$ & 25 & Feb 1988 & Minimal synovial thickening & $\begin{array}{l}10 \mathrm{ml} 1 \% \text { osmic acid }+\mathrm{TCH} \\
\text { Nov } 1988\end{array}$ & $\begin{array}{l}\text { No improvement. } \\
\text { Surgical synovectomy } \\
\text { Aug } 1989 \text {. Large nodule } \\
\text { and synovial hyperplasia. } \\
\text { Recurrence Jan } 1990\end{array}$ & $\begin{array}{l}185 \mathrm{MBq}^{* 1} \mathrm{Y} \text { Jan } 1990 . \\
\text { Small effusion } 1990 . \\
\text { See fig } 2\end{array}$ \\
\hline 4 & $\mathbf{M}$ & 26 & May 1989 & Minimal hyperplasia & $\begin{array}{l}10 \mathrm{ml} 1 \% \text { osmic acid + TCH } \\
\text { Dec } 1989\end{array}$ & Excellent May 1990 & \\
\hline
\end{tabular}



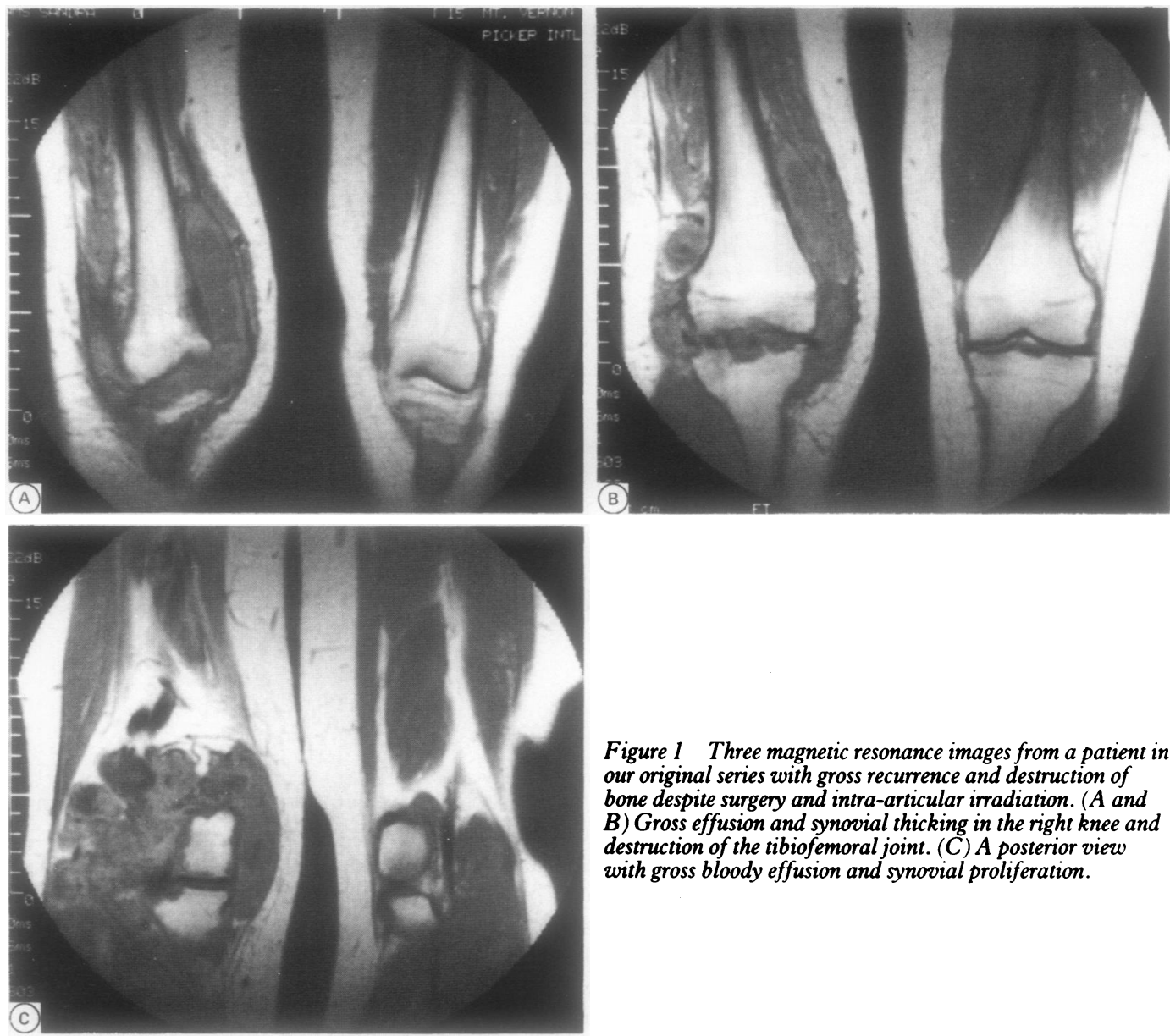

Figure 1. Three magnetic resonance images from a patient in our original series with gross recurrence and destruction of bone despite surgery and intra-articular irradiation. ( $A$ and $B)$ Gross effusion and synovial thicking in the right knee and destruction of the tibiofemoral joint. (C) A posterior view with gross bloody effusion and synovial proliferation.

evaluate. As can be seen osmic acid was also used, especially in our younger prereproductive patients, with the same variable response. The response to ${ }^{90} \mathrm{Y}$ in patients after synovectomy remains fairly consistent. This small series of patients has been particularly helpful in showing that no single treatment is spectacularly better than another and in reminding us how much still needs to be achieved.

Assessment before and after treatment poses another unresolved problem, not new to rheumatologists. In pigmented villonodular synovitis only one joint is treated, which at least avoids the difficulties posed by concomitant use of disease modifying drugs in rheumatoid arthritis. We attempted to assess our patients in a variety of ways. Simple measurements and volume of fluid may be helpful, but in most patients there is a great variation in size, pain, and swelling of the joint with exercise, which vitiates the use of such indices in young, energetic patients, who comprise the majority. A combination of computed tomography and double contrast arthrography proved useless in assessing synovial hyperplasia, and ultrasound scans provided too much scope for interobserver and intraobserver variability. Magnetic resonance imaging has proved helpful as it is possible to distinguish synovium and synovial fluid. Thus in patient No 3 (table 1) magnetic resonance imaging confirmed the area of maximum nodular formation. Magnetic resonance imaging thus shows promise in providing us with useful, reproducible measurements. Franssen et al used a technetium uptake measurement but obtained only variable correlations with clinical and other assessments ${ }^{4}$; their arthroscopic data were incomplete, and even unsuccessfully treated patients had apparently persistent disease at arthroscopy. We may have to keep the terms

Table 2 Patients with previous surgical synovectomy

\begin{tabular}{|c|c|c|c|c|c|c|c|c|}
\hline \multirow{2}{*}{$\begin{array}{l}\text { Case } \\
\text { No }\end{array}$} & \multirow[t]{2}{*}{ Sex } & \multirow{2}{*}{$\begin{array}{l}\text { Age } \\
\text { (years) }\end{array}$} & \multirow{2}{*}{$\begin{array}{l}\text { Date of } \\
\text { onset }\end{array}$} & \multirow{2}{*}{$\begin{array}{l}\text { Foint } \\
\text { affected }\end{array}$} & \multicolumn{4}{|c|}{ Stages of treatment and outcome } \\
\hline & & & & & 1 & 2 & 3 & 4 \\
\hline 1 & $\mathbf{M}$ & 33 & Oct 1987 & L knee & $\begin{array}{l}\text { Anterior synovectomy } \\
\text { Recurrence Mar } 1988\end{array}$ & $\begin{array}{c}\left.370 \mathrm{MBq}{ }^{*}\right) \mathrm{Y} \text { May } 1988 . \\
\text { Recurrence Sep } 1988\end{array}$ & $\begin{array}{l}10 \mathrm{ml} 1 \% \text { osmic acid }+\mathrm{TCH}^{*} \\
\text { Sep } 1988 \text { excellent. } \\
\text { Recurrence Dec } 1989\end{array}$ & $\begin{array}{l}10 \mathrm{ml} 1 \% \text { osmic acid + TCH } \\
\text { Mar } 1990 \\
\text { Recurrence May } 1990\end{array}$ \\
\hline 2 & $\mathbf{F}$ & 63 & Jun 1985 & L knee & $\begin{array}{l}\text { Anterior synovectomy } \\
\text { May 1987. Pain ++, } \\
\text { severe swelling }\end{array}$ & $\begin{array}{l}370 \mathrm{MBq}^{\left.{ }^{*}\right)} \mathrm{Y} \text { Sep } 1988 . \\
\text { Pain }++, \text { slight } \\
\text { swelling }\end{array}$ & $\begin{array}{l}10 \mathrm{ml} 1 \% \text { osmic acid + TCH } \\
\text { Jan } 1989 \text {. Pain }++ \\
\text { no swelling }\end{array}$ & $\begin{array}{l}\text { Arthroplasty May } 1989 . \\
\text { Pain ++ }\end{array}$ \\
\hline 3 & $\mathbf{F}$ & 22 & Apr 1985 & R Knee & $\begin{array}{l}\text { Anterior synovectomy } \\
\text { Dec } 1985 / \text { May } 1986 \text {. } \\
\text { Posterior synovectomy } \\
\text { Oct } 1986+\text { removal of } \\
\text { Baker's cyst. Recurrence } \\
\text { after } 18 \text { months }\end{array}$ & $\begin{array}{l}370 \mathrm{MBq}{ }^{{ }^{41}} \mathrm{Y} \text { Oct } 1988 . \\
\text { Marked improvement }\end{array}$ & $\begin{array}{c}\text { Asymptomatic in Feb } 1990 \\
\text { but } 4 \mathrm{~cm} \text { Baker's cyst }\end{array}$ & \\
\hline 4 & $\mathbf{F}$ & 39 & Nov 1985 & L knee & $\begin{array}{l}\text { Anterior synovectomy } \\
\text { May } 1986 \text {. Recurrence } \\
\text { after } 2 \text { years }\end{array}$ & $370 \mathrm{MBq}{ }^{91} \mathrm{Y}$ Nov 1988 & Asymptomatic Mar 1990 & \\
\hline 5 & $\mathbf{M}$ & 48 & Jul 1987 & $\mathbf{R}$ ankle & $\begin{array}{l}\text { Limited synovectomy } \\
\text { Jul 1988. Excellent } \\
\text { result }\end{array}$ & $\begin{array}{l}\text { Prophylactic } 92 \mathrm{MBq} \\
\text { Y Feb } 1989\end{array}$ & & \\
\hline
\end{tabular}



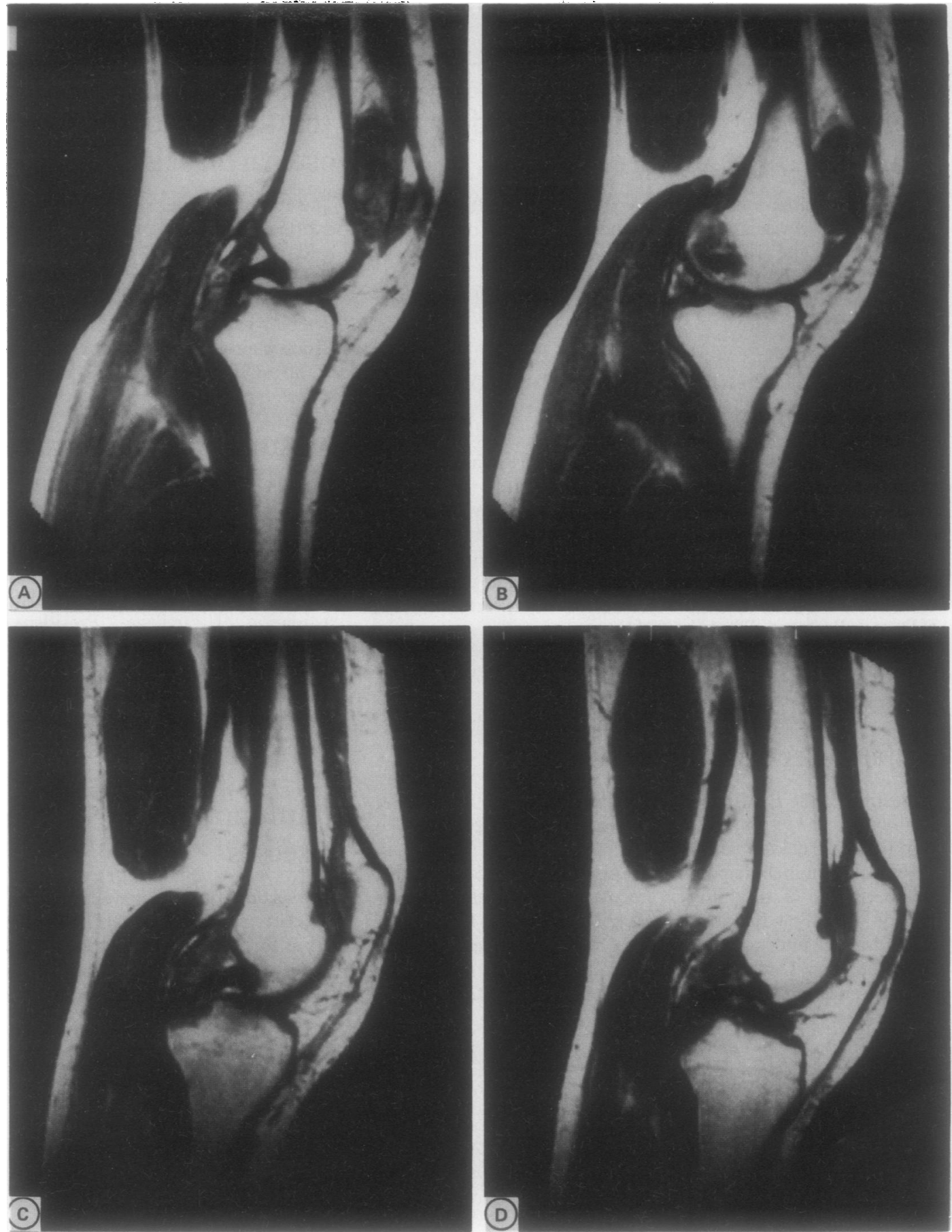

Figure 2 Case No 3, table 1. (A and B) Effusion, thickening, and nodules in the suprapatellar pouch six months after diagnosis and before treatment. Erosion of the anterior aspect of the femur above the condyles is clearly shown. (C and D) Similar views after osmic acid treatment, surgical symovectomy and $185 \mathrm{MB}$ q yttrium-90 nine months after the previous magnetic resonance imaging scan. There is no effusion, but the bone erosion is still present.

'excellent, good, moderate, and poor' responses for some time yet; at least these can be easily defined.

Clearly shown is the need for careful studies of suitable patients in centres with previous experience if progress in management is to be made. Close collaboration with orthopaedic surgeons is essential, and future treatment will perhaps include the use of arthroscopic synovectomy; even though this prospect arouses little enthusiasm at present.

\section{Northwick Park Hospital, \\ Watford Road,}

Harrow

J M GUMPEL D J SHAWE
1 Byers P D, Cotton R E, Deacon O W, Lowy M, Newman P H, Sissons H A, Thomson A D. The diagnosis and treatment of pigmented villonodular synovitis. I Bone foint Surg [Br] 1968; 50: 290-305.

2 Menkes C J. Chemical and radiation synovectomy in rheumatic diseases. Rherematol Rehabil 1979; 28: 65-77.

3 Williams P L, Gumpel J M. Use of yttrium 90 in diffuse pigmented villonodular synovitis after surgical synovectomy. foumal of Orthopaedic Rheumatology 1989; 1: 121-8.

4 Franssen M J A M, Boerbooms A M Th, Karthaus R P, Buijs W C A M, van de Putte L B A. Treatment of pigmented villonodular synovitis of the knee with yttrium-90 silicate: prospective evaluations by arthroscopy, histology, and $\%$ Tc pertechnetate uptake measurements. Ann Rheum Dis 1989; 48: 1007-13.

5 O'Sullivan M M, Yates D B, Pritchard M H. Yttrium 90 synovectomy-a new treatment of villonodular synovitis [letter]. Br $\mathcal{Y}$ Rheumatol 1987; 26: 71-2. 